\title{
The Art of the Self: Identity and Performance in Sunetra Gupta's So Good in Black and Kamila Shamsie's Broken Verses
}

\author{
Amaya Fernández-Menicucci \\ University of Castilla-La Mancha \\ amaya.fernandez@uclm.es
}

\begin{abstract}
This essay explores the intersection between art, performance and political agency in the quest for and building of self-identities in two novels by two Britain-based authors of the South Asian diaspora: Sunetra Gupta and Kamila Shamsie. Gupta's So Good in Black (2009) and Shamsie's Broken Verses (2005) provide a fertile ground for a critical comparison of the way in which each author understands and deploys the performative relationship between agency, creativity and identity. Following Marvin Carlson's distinction between 'positive' and 'negative' perspectives on social performance, the present textual analysis focuses on the fact that Gupta understands individual subjectivities to be overruled and dramatically reshaped by social roles and identifications, whereas Shamsie sees the performative nature of identity as instrumental in the opening up of 'liminal' spaces in which identity is negotiated and the process of selfconstruction can truly take place. This paper aims, therefore, at analysing the discursive strategies through which Gupta's and Shamsie's travel writers, actors, poets, dancers and political activists use both onstage and offstage performance to act 'against' socio-cultural (de)limitations and impositions and 'upon' external and internal realities alike-or fail to do so.
\end{abstract}




\section{Embodying the self, creating the self: performance, creativity and agency as forms of self-construction ${ }^{1}$}

And why do I demand of her an incessant composure when it is clear that some turbulence is much more likely to carry us to the port where we both really want to be, perhaps because I would wander those streets only as a coward, unsure of how to keep her and make her happy even though that is all my heart has ever desired. (Gupta, 2009: 268)

An American travel writer and a married Indian dancer are passionately in love with each other. Both seem, however, intrinsically incapable of bringing their feelings to fruition, to make their dreams come true, to 'make' - this is the key word - their love become real, substantial. There are those who are born doers, who are ready and willing to shape the world around them to suit their needs, who act upon external reality with a relentless problem-solving attitude. Then there are those who choose the path of least resistance and take refuge in the comfort of internal realities, much less arduous to conquer and shape than external ones. The following pages will discuss the way in which both 'doers' and 'dreamers' are represented in Sunetra Gupta's So Good in Black (2009) and Kamila Shamsie's Broken Verses (2005). Specifically, the present analysis will attempt to ascertain the role that performance plays in the process of selfconstruction undertaken by seven characters, three from Gupta's text - the travel writer, his lover Ela and her cousin Damini - and four from Shamsie's novel - Nazim the Poet, his lover Samina, their friend Shehnaz Saeed and Samina's daughter, Aasmaani.

Marvin Carlson defines performance as a term "so often encountered in such varied contexts that little if any common semantic ground seems to exist among them" (1996: 2). As far as Gupta's and Shamsie's novels are concerned, the notion of performance must indeed be approached from as many different angles as possible, for the texts in question are particularly abounding in instances of it which exceed the formal delimitations of artistic onstage performance. In particular, Gupta and Shamsie seem interested in describing performance as the achievement of a goal through a process that entails the active involvement of a subject. Out of the three denotative meanings of the term 'performance' proposed by the Shorter Oxford English Dictionary (2007), the first two define this concept as "the execution or accomplishment of an action or process" and as "the carrying out or fulfilment of a command, duty, purpose, promise" (my italics). In this sense, the process of self-construction of Gupta's and Shamsie's characters can be defined as the fulfilment of a promise to one's self, as an ongoing performance throughout which individual identity evolves until it reaches the desired level of independence from collective superstructures of power and is finally free from overbearing socio-cultural impositions. The same idea can be applied to the journey of self-definition of any given postcolonial, diasporic and/or 'globalised' citizen of today's world. The very notion of cultural hybridity, as defined by Feroza Jussawalla (1997: 20), requires a dynamic sense of individual identity that easily compares to performing different roles in different cultural and geo-political contexts. Both postcolonial and performance studies are particularly concerned with this transitional quality of self- 
identification, as Homi Bhabha's (1994) "third space" and Victor Turner's (1969) understanding of performance as "liminal" seem to suggest. To (re)locate the self anywhere on the social map implies readjusting one's manner of performing the said roles, so that 'performing' becomes tantamount to 'being' inasmuch as individual identity is composed of all the various manifestations of one's self in different situations. Identity is performed and performing one's identity means being someone, possessing a distinct subjectivity. Furthermore, performance, as it is understood here, embraces three main concepts: action, creation and embodiment. In order to be a subject endowed with an individual and independent identity, one must 'actively' engage in a process of self-definition that will 'create' a multidimensional self capable of being 'embodied' within a specific set of chronospatial coordinates. In other words, the process of self-construction, as contended by Nita Kumar (1994: 8-13), requires acting on both external and internal realities, constantly creating new forms for the self, as well as it requires being physically inscribed in a given socio-cultural and geo-political framework. This postcolonial perspective neatly dovetails into cultural anthropologist Kirsten Harstrup's (1995: 90) definition of the performance of the self as that of "one person, combining bodily and mental images in a unified performance", just like a dancer, performing on stage and creating new symbolic realities with their mind and body.

Out of all of Gupta's and Shamsie's novels, it is in So Good in Black and Broken Verses - respectively, Gupta's fifth and Shamsie's fourth novel - that the dimensions of socio-political activism, artistic creation and artistic performance are brought together and represented as three cornerstones of the process of identity construction by postcolonial, gendered subjects. These two novels, better than any other in Gupta's and Shamsie's literary corpus, will then provide a fertile ground for a critical comparison of the way in which each author understands and deploys the performative relationship between agency, creativity and identity. Specifically, in both novels there can be found a socio-political activist in constant intimate dialogue with a performer - two performers, in the case of Broken Verses - and a writer. Both novels can also be said to consist in a convoluted first-person narrative journey in search of the truth. What initially appears to be a quest for the true nature and real identity of an/Other eventually takes the reader to the centre of the narrator's self, so that it is the latter's identity that is finally questioned, exposed and (re)constructed. In "Indian Women Writers: Confession and Self-Making", Padmini Mongia discusses precisely this propensity, among women writers of Indian origin, to use a "confessional voice" defined "not only through the obvious signification of the first-person narration but as a mode of representation [...] in which the text defines itself as an utterance of revelation for the implied audience" (2001: 298). Although the process of narrating the self is not necessarily a performative act in itself - as is the case with oral storytelling -, self-narrative is configured here as a dramatic monologue that addresses both a fictional and a nonfictional audience, while engaging, at the same time, in a lifelong dialogue with other characters. In this dialogue, life is represented as a succession of performative acts, of roles enacted and scripts played out in a variety of social contexts. Thus, on the one hand, the narrative process in 
So Good and Broken Verses is indeed an act of revelation of the self to the self. On the other hand, both texts are constructed as a dialogue with a number of significant characters, who function as interlocutors and mirror the narrator's self. In fact, in both novels interpersonal relationships are organised in a triangular structure. At each corner of the triangle, we have a specific set of characters: the activists, the onstage performers, the non-performative artists. In turn, each of these can be also said to fall into one of the two categories of individuals mentioned at the beginning of this paper, the 'doers' and the 'dreamers', so that we have at least one representative of each category in all three groups of characters. To the first category belong those characters who are successful performers, that is to say, who succeed in constructing their individual identity by freeing themselves of social pressure and cultural impositions. To the second category belong those who 'dream' of attaining such freedom, but take no action towards becoming one with the desired persona. The analysis of the novels in question has been divided, therefore, in two sections. The first concentrates on how performance, be it political or artistic, and art, be it performative or not, are used by Gupta's and Shamsie's characters as fundamental tools to define their identity. It will pay particular attention to the way each character gains awareness of their individuality by identification with a certain form of art or socio-political activism. The second section deals, on the contrary, with the way in which the said characters use their performative talents to define themselves in opposition to certain collective identities and socio-cultural institutions. In this case, their performances are deployed as strategies of empowerment that allow them not only to develop further their identity, which will thus grow more complex, but also, and most importantly, as active mechanisms of defiance of both publicly authoritarian systems and privately imposed roles.

The fact that the process of identity construction is central to the writings of both novelists constitutes the main reason why many find their work so compelling (Majumdar, 2002; Mandal, 2006; Nasta, 2002: 232-239). Far from limiting their narratives to a pendulous movement to and from Eastern and Western shores, Gupta and Shamsie invest the diasporic subjects in their novels with the ability to range freely among such a vast array of (sub)cultures that the term 'global subjects' seems appropriate description. The obsessive re-encounter with the 'imagined homeland' (Rushdie, 1992) in Gupta's narrative contrasts, however, with Shamsie's embrace of the homeland as a haven never to be parted with, neither physically nor spiritually. This point will become especially significant in the following analysis, since this tendency to 'imagine' life rather than to live it compels Gupta's characters to become what I call 'dreamers', always on the verge of attaining completeness and fulfilment, but never quite managing to do so. Agency, the ability, that is, to transform external reality - by creating new referential realities or, at least, new interpretations of the same realities and causing events to happen, is almost absent in Gupta's novels, whereas it is central to Shamsie's. In the former's narrative, both male and female characters seem cursed with a constitutional incapability for action. Like postcolonial Hamlets, they spend their lives asking existential questions and strenuously looking for answers that might help 
them along the process of self-construction, the single activity that seems to consume their existence and to which everything else is subservient. As Bruce King puts it, Sunetra Gupta "belongs among the fabulists [...]. If myth, literary models, parody and the improbable disrupt mimesis, it is because Gupta, a scientist, has a surprising interest in the non-scientific, the surreal, the witty and amusing" (2004: 279). Her characters are artists, scientists, and performers who do not extend their creativity beyond the strict boundaries of the artistic/scientific sphere. What they create, that is, lives only in a selfreferential reality, coiled onto itself and unaffected by other realities in the same way that other realities are perfectly unaffected by, and sometimes even unaware of, such artistic/scientific acts. Art and science are, thus, tools to inform self-contained spheres, a means of escape from what is beyond the self. Agency, on the other hand, is the means through which the self reaches out into collective spheres, external realities and other subjectivities with the ultimate intention of 'making' a difference, of bringing about changes. Agency is action intended to generate a reaction. Despite the very similar social conditions displayed in both novels - in terms of social class, gender and formal education -, only in Shamsie's novel are there successful 'doers' who end up constructing an independent identity for themselves and performing it unrestrictedly. To quote Carlson (1996: 39) again, perspectives on social performance can be classified according to two broad categories: what he calls "negative" and "positive views." The former stress the stifling effect of social roles, which "tend to deny or subvert the activities of a 'true' self" (39). The latter conceive social performance as the fertile ground in which "roles do not emerge from the self, but the self emerges from the roles" (39-40), leaving room for a "potential, if qualified, agency" (188) that Judith Butler (1993: 94) theorises as resisting hegemonic social discourses. As we shall see in the following two sections, Gupta's characters clearly exemplify the first perspective, while Shamsie's novel illustrates the second.

\section{Performing the self, narrating the self: gaining awareness of one's subjectivity}

The American travel writer mentioned at the beginning of this essay is the first-person narrator and focaliser in So Good in Black (henceforth, So Good). His playing both roles at once makes him the character whose process of self-identification depends the most on how he relates to the triangular network described earlier on. Max Gates has been professionally reporting impressions and anecdotes from his travels for the past eight years, but for decades, he has strived to become a novelist. With the passing of time, and in spite of his struggle to succeed, it finally dawns on him that he is utterly unable to produce even a short story. Nevertheless, the urge to become a writer has been shaping his life since his college years. Ever since his best friend, Piers O'Neil, pronounced him a novelist, Max Gates has defined himself as such. However, it is only when he starts using writing to translate into words the physical act of travelling, of observing external reality, that he succeeds not only in finding a career but also in giving his life a clear purpose and, consequently - or at least apparently -, in finding a 
path towards self-discovery. In other words, it is only when his artistic creativity begins to do something physically that he blooms as an artist. It follows that, despite the fact that the act of writing does not traditionally belong to the performative arts, Max Gates's literary efforts exist because and as long as they are begotten through a series of physical actions that are revealed to a public.

$\mathrm{He}$ is a performer, albeit a private one, but he certainly is no 'doer'. No active problem-solving for him, no active engagement with external reality. That he is cursed with a blurred existence and an equally indistinct identity seems to be confirmed by the fact that it is always other people's perceptions of him that prompt him to reshape his own self in order to conform to those external expectations. Interestingly, Byron Mallick's wording of his suggestion for Max's career is as follows: "If I were you, I would try my hand at something that is not fiction. [...] Like travel writing" (Gupta, 2009: 67). To put it briefly, 'write about what you have experienced'. The focus is thus on the idea that Max's creativity is inextricably linked to his experience. To quote Susheila Nasta, lack of creativity relegates artistic efforts to an exercise in selfnarration, to a "hazardous journey into the making of subjectivity itself" (2002: 233). However, since Max must first experience and then narrate, there exists a chronological detachment between the physical and the intellectual dimensions of his art. This makes his a much more fragmented identity, while it also highlights his tendency to recreate external realities through the filter of his internal biases. In this, he reveals himself to be what I have dubbed a 'dreamer', someone more readily disposed to imagine and reshape reality in the abstract than to confront it and take action to change it.

Narrating is thus to Max what performing - artistically or otherwise - is to other characters: a means to probe and search for an identity of their own. The same is true for the first person narrator and main character in Shamsie's Broken Verses, whose account of present and past events is equally comparable to a quest for her self. Her narrative consists in a discursive journey in search of her mother, disappeared many years before. By looking for and finding different versions of her mother's life and identity, Aasmaani happens to gather a deeper knowledge of her own self, which had escaped her so far. In fact, neither Aasmaani nor Max Gates possesses a clearly defined call in life, and so they both lack a clearly outlined identity. In a certain way, like the nameless protagonist of Daphne Du Maurier's Rebecca (2003), both seem to become better known to the reader through their relationship with others, rather than being endowed with their own facial features and a distinctive profile. In this regard, Shamsie has even gone a step further, literally providing Aasmaani with an upper part of her face stunningly identical to her mother's.

[S]he stepped forward and held up her hand to cover the lower half of my face so all she could see were my eyes - grey with a starburst of green in the centre - and my high forehead and straight, black hair.

'Amazing,' she said. 'Isn't it amazing?' (Shamsie, 2005: 8)

Always shadowed by her mother's celebrated activism, her successes, political visibility and personal charm, Aasmaani has had to fight all her life in order to construct an 
identity of her own. However, in her various attempts to do so by identification or by opposition, she has always seen her ambitions frustrated. When, as a child, she tried to emulate her step-father's convoluted use of language or when, as an adolescent, she attempted to imitate her mother's political courage and her performance of the role of a public demonstrator, Aasmaani would feel she was either inexcusably betraying the figure of her biological father or that she was being belittled and rejected by the inimitable perfection of her mother and of her mother's lover, the nation's greatest living poet. As her half-sister Rabia, puts it, "[i]s it that you don't want to be your mother, or that you are afraid you'll fail so dismally to live up to her that you won't even try?" (28). For the most part, however, it is the impenetrability of the relationship between the Poet and Samina that leaves Aasmaani in a corner, unable to feel equal to either. The Poet and the Activist would share everything, experience everything together, mirror each other's performances, albeit through different means. There was indeed little room left for a third party. Aasmaani had to learn the secret language of their unparalleled relationship unaided and unacknowledged by them, literally memorising the code in which they encrypted their correspondence so that she too could be part of those aspects of her mother's and her symbolic father's life from which she was otherwise excluded.

"I was the girl who could be anything - that's what my teachers used to say, and I believed them. I just never realised that 'anything' could include this" (70), reflects Aasmaani at the beginning of the novel. Her refusal to accomplish anything, to perform any roles, to create anything at all, makes her, at the beginning of her journey, even less of a 'doer' than Max Gates is. However, she will finally prove herself to be one once she manages to take affirmative action against those characters who were manipulating her existence, emotions and identity. If Max Gates's process of self-definition culminates when his friend Byron Mallick provides him with a new identity and a new profession, Aasmaani's process of self-construction begins once she realises she has been a victim of her mother's and the Poet's memory, which had been effectually manipulating her into believing she was a worthless nobody. Asmaani's narrative is then to be considered as 'performative' in that, like a perlocutionary act, it causes Asmaani to perform a series of actions and, through these actions, it triggers a neverending process of identity construction.

Aasmaani Inqalab and Max Gates share one of the three corners of the triangle that maps the configuration of political activism, artistic performance and identity construction. On the second corner are located the poet and the actress in Broken Verses and the dancer in So Good. These are performing artists in a strictly conventional way. Even though poetry might not be usually numbered among the performative arts, Nazim the Poet regularly delivers his verses orally to his audience, thus returning poetry to its original connection with the Greek idea of poiesis, the act of 'making' merging into the act of 'doing'. That is to say, he performs his art like the aoidoi of old and, in this sense, he has the same claim to being considered a performer as his beloved Samina, the feminist political activist in Broken Verses. Art is a form of political resistance for the former, whereas political activism is a form of art for the latter. Poetical and political 
orators alike are then unquestionably to be included among the rows of performers in Gupta's and Shamsie's literary cosmos, for their public elocutions bring them closer to the figure of the actor than to that of the novelist, journalist or essay writer. An actor bestows the substance of physicality, of his own body, on the abstraction of language, whereas a writer distils his or her art in disembodied, albeit referential, linguistic symbols. It follows that public speakers, whatever their intention, must needs be performers in that they give form and substance to their thoughts with the physical dimension of their voice, countenance, gesture and poise.

All three of the aforementioned artists start defining themselves as performers at a very early stage in their lives and they are all acclaimed as such by a large, enthusiastic public. Hence, their defining identity is not something entirely imposed by others, as we have seen is the case with Aasmaani, nor is it the consequence of the subject's choice to identify him/herself with a certain image projected onto them by someone else, as happens to be Max Gates's case. This second group of characters assert their subjectivity by stepping onto a stage and declaring to the world at large "here I am", almost imposing, we might say, their own version of themselves on the external world. Shamsie, in particular, uses the Italian term "sprezzatura" (32) to describe the easiness with which Shehnaz Saeed, Pakistan's greatest actress in the fictional cosmos of Broken Verses, becomes one with her art in both speech, movement and emotion. What the public hear and see and feel when these performing artists stand tall, even arrogant, on stage is each performer's true self, a perfect example of the embodiment of the self in the here and now. Regardless of the fictional role he or she might be playing, the performer is one with the complexity of his/her multilayered subjectivity.

Things become more complex when it comes to analysing the character of Ela, Max's adulterous lover in So Good. Just as Max Gates had been indicated the path to follow - travel writing - by the ambiguous figure of Byron Mallick, so Ela has had her eyes opened to the beauty of dance by the same eccentric Indian millionaire. Mallick, who is well known in the upper circles for his exquisite taste and love for art, has not only encouraged the "graceful maiden with a great talent for dance" (Gupta, 2009: 46) to take classes but has also hired the best teachers in Calcutta. Once her art had reached an indisputable grade of perfection, he had enthusiastically undertaken the task of securing her venues, first in her hometown and then internationally, frequently accompanying her to Paris and London. Like an Indian Pygmalion, Mallick moulds Ela to his liking, taking every pain to see her potential enacted, her talent bloom, but also, to a certain extent, to turn her into an exquisite piece of living art. Initially, it is her mother's love of Bharat Natyam, a "South Indian style of temple dancing" (52), that introduces Ela to this form of art when she was still living with her parents in Ghana. Ela's parents' desire that she should be initiated in every aspect of their native culture will eventually take her to those ethnic dance classes and then to a boarding school in Calcutta. Therefore, dance is at first represented as a symbolic way to inscribe her within a collective ethnic identity. Then it is Mallick's passionate romance with all that is sublime that shapes Ela's talent, thus making her identification with dance again derived from someone else's identity. The same process takes place for the third time 
when Ela's passion for dancing has ceased to be a locus of identification for her and she derives her sense of self from her relation to an/Other, deliberately choosing motherhood as her primary site of identification.

Likewise, the character of the Poet in Broken Verses also appears to question the vocation that so early in life had consecrated his identity as an artist both in his public's eyes and in his own. Universally known as the Poet, he is Pakistan's most beloved contemporary poet, a national figure of unarguable stature. His identity is then mirroring, at least partly, what the public sphere perceives in him. This raises questions as to the extent to which his identification with his artistic self is a consequence of external projections. Interestingly, though, the pen name he chose for himself in his early youth is Nazim, which means precisely 'poet' (Shamsie, 2005: 84). Partly a homage to the Turkish poet Nazim Hikmet, this choice settles the matter and establishes his art as the identitary axis around which his whole subjective dimension revolves. What is Aasmaani's surprise when years after his murder, she believes to have found a letter with the Poet's confession of his inability to write poetry any more, of his having lost the very ability to write in Urdu: "[s]hould I tell you I can't write poetry any more? Poetry? I can't write Urdu" (112). Can the Poet be and not be a poet? The answer, yet, is no, as the ending of the novel reveals that the letter in which those words had been penned had been forged by Eddie, Shehnaz Saeed's son and Aasmaani's lover, in an attempt to manipulate first his mother and then his lover. The Poet's identity has survived the probing scrutiny of Aasmaani's and the reader's gaze and has resurfaced unscathed and shinier than ever in its integrity. Indeed, the Poet is one of the few characters to be found unquiveringly rooted in the identity that defines them from the start. This is so because his role as a renowned poet was self-chosen and supported primarily by his talent. It follows that, far from being an identity imposed by a collective Other, his being a poet, nay, the Poet is not an idea projected onto him but by him.

The third group of characters, that of the political activists, consists of Damini in So Good and Samina Akbar in Broken Verses. The performing artists in both novels are not the only characters whose process of self-definition is a matter of personal choice. As far as the activists are concerned, it is so evidently a matter of personal vocation that Samina's and Damini's decision to devote their lives to fighting social inequalities and injustice does not count with their families' approval and is certainly openly and even violently opposed by the most conservative and powerful circles in, respectively, Pakistan and India. As already noted, in both Gupta's and Shamsie's novels, sociopolitical activism is an art in itself and its representatives are endowed with the same gracefulness and charm on stage as Shehnaz Saeed and Ela are, which makes them performers in their own right. Samina Akbar is not only exceptionally beautiful: her "grazia" (32) makes her a performer who enchants the masses with her movements and oratory skills, as well as with the actual content of her speeches. "[C]rowds chan[t] her name as if she were a religion", she, "the Samina Akbar of blazing eyes" (59). Likewise, Damini oozes a powerful natural charisma that permeates her whole self, but is strongly rooted in her body. She would " $\operatorname{mov}[\mathrm{e}]$ with an angular purpose that 
immediately fascinated [Max Gates]" (Gupta, 2009: 7). It is with the same admiring pleasure with which the spectator's eyes follow the performer around the stage that he will follow Damini in her daily trips to the most depressed rural areas, where she would gather scorching examples of social injustice for her newspaper. It is impossible not to notice that gender plays a key role in the representation of both activists and performing artists. The fact that both Samina and Damini exude such fascinating elegance and are admired as much as if they were celebrities of the performative arts is intrinsically rooted in their being perceived and represented as feminine. The Poet was also acclaimed whenever he performed on stage and "the crowd - often numbering in the thousands - would roar with delight and repeat the rhyme and refrain back to him, shaking the edifices of buildings around them with the sounds of poetry" (Shamsie, 2005: 84). Nevertheless, his performances are never judged in terms of his physical gracefulness. In fact, although his appearance is considered "underwhelming, at best [...] no one objected to [his] playing the part of the impassioned young Qais" (50), the hero in a play adapted from one of his poems. The Poet's performance still undoubtedly consists in the same holistic intervention of body, soul and mind, but the ugliness or lack elegance of the male body does not prevent the performance from constituting an embodiment of the performer's self nor does it lessen the beauty of the performative act. Conversely, the beautiful, graceful bodies with which Samina and Shehnaz perform on stage are particularly dear to the public.

\section{Acting and reacting: performance as a site of resistance}

So far, the main characters in the two novels have been grouped according to their method of self-definition: narrativity, artistic performance or social activism. In this section, however, they will be analysed individually according to two criteria. The first question to be raised is up to what extent their process of self-construction relies on opposing, challenging and actively fighting the hegemonic power system in the geopolitical landscape they inhabit or whether they simply resist external pressure passively. The second and final point to discuss is the level of success with which each character provides his or her self with an articulated identity. The bottom line here is that some characters, although indisputably endowed with a most definite individuality and even complex subjectivity, fail, nevertheless, to free themselves from the incessant tugging of socio-cultural imperatives, to the point that the identity they have fabricated for themselves - or have allowed others to invest them with - becomes a hollow carcass, a heavy, meaningless, imprisoning armour. Other characters, however, do not stop their process of identity construction after having reached a point of comfortable self-definition, that is to say, after having found a convenient balance between the need to locate oneself on different social maps and the necessity of distinguishing oneself and developing a personal sphere of self-recognition. These characters are the 'doers'. They are the ones who, not content with simply gaining awareness of their unique individuality, busy themselves to evolve and make the world evolve with them. 
We have seen that the very moment the Poet dubbed himself Nazim he was declaring his utter and complete identification with his art, as if nothing else in life could explain his nature. The Poet's real name, however, is Aashiq, which too has a literal meaning: 'beloved'. "It's not a name, it's what I am to Samina" (Shamsie, 2005: 328). Therefore, love, like poetry, is responsible for shaping his identity. Unlike Max Gates, who is unable to let his identity develop beyond the convenience of his identification with his art and profession, the Poet embraces his love for Samina as an equally defining aspect of his self. He does the same when he accepts Aasmaani's nickname for him, 'Omi', as a third cornerstone of his identity, in this case, that of a symbolic father to Samina's daughter. Likewise, Shehnaz Saeed, whose process of selfdefinition as an actress seemed to have stripped her of every other possible term of identification, finally finds herself starting a process of self-construction through her art, her motherhood and her sexual identity. Her love for Samina and her motherly interest in her son's relationship with Aasmaani are eventually found to be the same rescuing forces that had already saved the Poet and Samina from the collectively imposed curse of a one-dimensional identity. Unlike Samina's, Shehnaz's is not a public revolt against a military dictatorship and an unbearably patriarchal society. Still, her performances on and off stage generate a snowball effect in the lives of others that is no less significant than Samina's political achievements. Shehnaz Saeed represents thus the quintessential performer, as her life, both on and off stage, is an ongoing sequence of actions that create new realities in the eyes of others. What is more, thanks to Samina's friendship first and then to Aasmaani's empathy, Shehnaz embraces her identity as a lesbian along with her motherhood, thus consolidating in one single identity what society had forced to stay fragmented. She then embodies, as performing artists do, the emotional, the spiritual and the intellectual in the tangible dimension of her body.

Ela, on the contrary, far from finding unity in her private sphere and emotional dimension, is haunted by the contradicting nature of her life, contradicting, that is, due to the rigid gender polarisation of Bengali society. The responsibilities of married life, motherhood and the destructive shadow of adultery weigh heavily on this woman's chances of self-development. "[B]ut what matters to you of what comes after? Only my child, she says with absolute conviction" (Gupta, 2009: 144). Ela declares that the most important thing for her is her daughter, which can sound like a pitiful attempt to justify the fact that she has no longer time to dance. Yet, motherhood is the only act of creation that seems to satisfy her. Is it so because she is now the one who is moulding another identity, as her own parents and Mallick once used to do? Or could it simply be that she is now rebelling against an identity that was first imposed on her as a way to reinforce her ties with the Bengali ethnic community, and then as a way to please her otherfather? Unlike Reba, the gifted musician in Gupta's A Sin of Colour (1999), Ela does not use her performances to escape the asphyxiating limitedness of the domestic sphere and her role as a wife and a mother. She actually uses motherhood and her role as a wife to escape from what has turned out to be an imposed identity, that of the artist who is no longer fulfilled by her art. If Ela, like Max Gates, eventually fails to find her true self, it is solely because, instead of allowing her to explore different possibilities, her social 
environment only gives her a choice between performing the role of a dancer or that of a mother and wife. In her own words, in her life there is "much to anchor [her], but very little to guide [her]" (Gupta, 2009: 121), to guide her, that is, towards new horizons.

Unlike Ela, Damini and Samina, the energetic activists, never stray from the path that will lead them to their self-imposed goal. Damini's devotion to the cause of the poor and the forlorn takes first a narrative form, as she becomes a reporter specialised in social injustice. In time, however, she will exchange this approach to social activism for a performative one, as she decides to "giv[e] up journalism in favour of a more silent engagement with the purpose of delivering the world of oppression" (23). By founding a shelter for battered Nepali women, Damini steps off the stage, retreats from public life, and begins performing a service that contributes to the fulfilment of her identity more than journalism could ever do. Samina favoured, instead, the visibility that loud protest and practical subversiveness provide. Samina's opposition to the Pakistani military regime and her stern defence of women's rights in the face of a radical enactment of Sharia law is reason enough to consider her the most belligerent activist in Shamsie's work in general. Her performing the role of one of the leaders of the people's fight against Pakistan's repressing regime is proof enough of her active engagement in influencing and changing the world around her. The countless rallies she led against the enforcement of the most misogynous laws and the many times she was imprisoned for her rebellious speeches and her activism in providing the poorest among Pakistani women with legal counselling are all evidence of subversive agency and active resistance. However, after the Poet's brutal murder, Samina's empowered subjectivity suddenly implodes and she is last seen walking towards the ocean. Exit the performer. Aasmaani's sense of loss is mostly due to her reading of Samina's disappearance not as a suicidal act, as everybody else thinks, but as the forsaking of a child by her mother. In this, in fact, resides Samina's capitulation to hegemonic collective forces. Like Ela and the Poet, she prizes the fullness of her self above anything else. Once deprived of one aspect of her threefold identity - as mother, activist and lover -, Samina's subjectivity crumbles. "I would not allow them to tell me there was a choice to make between motherhood and standing up for justice," (Shamsie, 2005: 90) she used to say. But years later her daughter would rightly wonder: "what about the choice to be made between motherhood and romantic love?" (90). The fact the Samina chooses death over a life without her beloved Aashiq might be viewed as a structural weakness of this heroic figure: the sort of Achilles's heel that re-humanises the idealised figure of the acclaimed performer of deeds of social justice. But there is more to Samina's character than this.

When did my mother realize all of this and seek to break out of the character she and the world had invented for her? When did she see she couldn't successfully achieve that breakout so long as she was in the company of anyone who would try to re-impose that old narrative of character on to her life? (143)

The Poet and Samina had to be faithful to the character they had constructed for themselves and which, in time, had become of public domain, just like Shehnaz's. The difference consists in the fact that, while the actress finds a way to break through what 
used to be an identity of her own doing but has now become a stiff corset, the Poet and Samina are buried beneath their need to stick to the one and only identity configuration they have built for themselves and ever known. To quote Judith Butler (1993: 2-3), the performativity of their identities of choice is citational in that their actions and activism, their art and creativity reproduce their respective selves through a referential repetition of their identities' constitutional constraints.

Samina's and the Poet's lack of flexibility when it comes to allowing their identities to grow and duck and dodge is what, eventually, kills them. Their inability to sacrifice a little has led them to sacrifice it all. They cannot cope with loss, so they lose everything. Max Gates's failure, on the other hand, is a consequence of the contrary, of his "enduring the many possibilities of [his] narrative and never gathering the conviction to be faithful to any one of them" (Gupta, 2009: 36). His water-like adaptability, his inability to commit himself to anything and his unwillingness to risk anything spare him from pain, but also prevent him from feeling fulfilment and happiness, his life "unmarred by either pain or ecstasy" (37). Samina and the Poet could never learn to lose; Max has never learnt to win. Conversely, like Shehnaz's, Aasmaani's success in finding her true self and, what is more, an identity that is no longer a poor, inadequate reflection of the greatness of others, depends on her being able to overcome any rigidity in her definition of her self. Perfection, elusive as it may seem to be, when attained in Shamsie's novels, closely resembles a hieratic statue, a petrified version of the divine. It is only in the quickness of the ever-changing dynamism of an evolving 'identity performance' that characters of whatever age succeed in defining and developing their selves. In Gupta's novel, however, not one character achieves the level of completeness necessary to fulfil themselves. Max, a truly diasporic subject, a rootless, homeless, Western man, represents a former hegemonic Self now powerless to find his own self. In this character, Gupta seems to point at the white male crisis of which much has been said of late. Nevertheless, the main difference between Aasmaani and Max Gates does not reside in their respective gender, or in the generation to which they belong. What sets them apart from each other is the fact that, while Max finally defines himself through his art, identifying as a travel writer and thus as a wandering subject, Aasmaani will finally break through the circle of identification/rejection. Instead of relying on external definitions to don her self with an individual, subjective, unique identity, she will eventually find an independent way to build herself an identity that is unmistakably her own.

This last remark calls for a final clarification of one of the aspects that differentiates Gupta's novel from Shamsie's. In the former, characters rely more on a process of selfdefinition than on one of self-construction, which is the reverse of what characters in Shamsie's novel do. Self-definition is an intentional, though less active process which mostly takes place by identification with or opposition to external realities. Such realities mostly comprehend collective identities, superstructural entities and sociocultural institutions, although the pressure of collectively imposed roles is often represented by stifling interpersonal relationships. In Broken Verse, characters like Aasmaani and Shehnaz embark on a process of self-construction which can be defined, 
borrowing Naz Rassool's (1997: 191) words, as an 'active' "re-appropriation of the categories of racialised and genderised subjugation and the process of encoding these with empowering meanings as part of the struggle to gain control over their lives." The fact the Max Gates fails to construct his identity independently - even though he does find himself a profession that feeds off his natural talents - is representative of the radically different way in which Gupta's and Shamsie's characters understand, experience and develop their individual selves through the process of 'performing' one's self. In So Good, not one character is able to apply, at one time, all three criteria of which any performance consists - action, creation and embodiment - to their own lives. In Broken Verses, on the contrary, Shehnaz Saeed and Aasmaani Inqalab eventually manage to merge a newly found control over their lives with the ability to create new scenarios, brand new dimensions for their selves, as well as with a sense of embodying their potentiality at any given moment in any given space. Both the traditional onstage performer and the offstage one translate the concepts of personal agency, creativity and embodiment to every aspect of their lives, thus finally enacting, creating and embodying their own identities.

\section{Notes}

1. This term is used here in the same way Padmini Mongia uses the term 'self-making' (2001: 298-301) and Naz Rassool the term ‘self-identification' (1997: 191).

\section{References}

Bhabha, Homi (1994): The Location of Culture. London: Routledge.

Butler, Judith (1993): Bodies that Matter. On the Discursive Limits of "Sex." London: Routledge.

Carlson, Marvin (1996): Performance. A Critical Introduction. New York and London: Routledge.

du Maurier, Daphne (2003) [1938]: Rebecca. London: Virago.

Gupta, Sunetra (1999): A Sin of Colour. London: Phoenix.

- (2009): So Good in Black. New Delhi: Women Unlimited.

Harstrup, Kirsten (1995): A Passage to Anthropology. London: Routledge.

Jussawalla, Feroza (1997): "South Asian Diaspora Writers in Britain: 'Home' versus 'Hybridity'." In Geoffrey Kain, ed., Ideas of Home. Literature of Asian Migration. East Lansing, Michigan: Michigan State University Press, 17-37.

King, Bruce (2004): The Internationalisation of English Literature. 1948-2000. Oxford: Oxford University Press.

Kumar, Nita, ed.(1994): Women as Subjects. South Asian Histories. Charlottesville, Virginia: University Press of Virgina.

Majumdar, Saikat (2002): "Modernist Aesthetics and the Fiction of Amit Chaudhuri and Sunetra Gupta." Modern Language Association 117(6): 138-155. 
Mandal, Somdatta (2006): "Calcutta Syndrome: A Study of Sunetra Gupta and Jhumpa Lahiri." In Thota Vinoda and Potlapalli Shailaja, eds., The Expatriate Indian Writing In English. Vol. 3. New Delhi: Prestige, 154-168.

Mongia, Padmini (2001): "Confession and Self-Making in the Fiction of Contemporary Indian Women Writers." In Jacqueline Bardolph, ed., Telling Stories: Postcolonial Short Fiction in English. Amsterdam: Rodopi, 293-301.

Nasta, Susheila (2002): Hometruths. Fictions of the South Asian Diaspora in Britain. New York: Palgrave.

"Performance" (2007): The Shorter Oxford English Dictionary on Historical Principles.

Rassool, Naz (1997): "Fractured or Flexible Identities? Life Histories of 'Black' Diasporic Women in Britain.” In Heidi Safia Mirza, ed., Black British Feminism. A Reader. London: Routledge, 187-204.

Rushdie, Salman (1992): Imaginary Homelands. Essays and Criticism 1981-1991. London: Penguin Books.

Shamsie, Kamila (2005): Broken Verses. London: Bloomsbury Publishing.

Turner, Victor (1969): The Ritual Process: Structure and Anti-Structure. Chicago: Aldine Publishing Co. 